\title{
Promoting the Spa Tourism Industry: Focus on Coastal Resorts in Kenya
}

\author{
By Roselyne N. Okech ${ }^{*}$
}

The connection between health and tourism is not a new phenomenon since people began to travel to spa towns in the 1800s and has grown substantially worldwide. Health retreats and spas are a rapidly growing sector of the tourism industry where there has been new interest in "new age" remedies and traditional remedial therapies. There is a distinct lack of published research on spa tourism issues in Kenya. Hence, the focus of such research could help identify the potential of spa tourism among domestic and international travellers, who visit Kenya and in particular Mombasa as a tourism destination. This paper aims to provide a profile of the spa resort sector in Kenya based on an in-depth analysis of promotional materials produced by each of the resorts within the population and discussions with managers of the spa resorts. The research aimed at providing a starting point for understanding the Kenyan spa resort market by establishing a preliminary profile and categorisation of the sector, particularly from a supply perspective. This research also seeks to provide some guidance for managing the prospective growth of the spa resort market and guide the marketing endeavours of existing spa resorts. Qualitative research was used to undertake an analysis of promotional materials produced by Kenyan spa resorts as well as in-depth interviews with the spa managers and direct observation. This was with the aim to establish reliable industry benchmarks for key infrastructure and generate greater awareness of the spa industry in Kenya to promote growth in visitation numbers. Keywords: Health, Kenya, Mombasa, Resorts, Spa, Tourism

\section{Introduction}

Health tourism is attracting tourists a great deal. The term includes spa and gym, Naturopathy, Yoga, Meditation and many other mental and physical exercises and treatments that are beneficial for health and rejuvenation (Table 1). The term spa comes from the Latin acronym sanitas per aqua, or 'health through water' and is broadly defined as water-based and non-water facilities offering a range of health / medical / beauty / relaxation treatments. It took until mid-1980s when some forward thinking resort operators added spas to

\footnotetext{
*Assistant Professor, Memorial University of Newfoundland, Canada.
} 
their properties (Madanoglu and Brezina, 2011; Montenson and Singer, 2004). Yet back in 1980s, having a spa facility in a resort was considered a luxury since a spa was deemed more of an amenity than an independent profitgenerating center for resort properties. Today, in the new millennium, the spa experience moves beyond being a luxury commodity (Foster and Mandelbaum, 2005). In 2007, the Global Spa Summit commissioned the Stanford Research Institute to examine not only spa revenues but spas' financial effects on related businesses (Stanford Research, 2008). Based on a study in 261 nations, Stanford Research estimated the total size of the global spa economy at $\$ 254.8$ billion in 2007.

Table 1. Spa Facilities Classification

\begin{tabular}{|c|c|}
\hline Type of Spa & Definition \\
\hline Day & $\begin{array}{l}\text { A day spa offers a variety of spa services, including facial and } \\
\text { body treatments on a day-use-only basis. }\end{array}$ \\
\hline Resort/hotel & $\begin{array}{l}\text { A resort/hotel spa offers a spa, fitness and wellness services, as } \\
\text { well as spa cuisine menu choices and overnight accommodations } \\
\text { within a resort or hotel }\end{array}$ \\
\hline Destination & $\begin{array}{l}\text { A destination spa is not part of another resort of hotel. The } \\
\text { destination spa's primary purpose is guiding individual spa-goers } \\
\text { to healthy lifestyles. Historically an extended stay, this } \\
\text { transformation can be accomplished by a comprehensive program } \\
\text { that includes spa services, physical fitness activities, wellness } \\
\text { education, healthful cuisine and special interest programming }\end{array}$ \\
\hline Medical & $\begin{array}{l}\text { A spa in which a full-time, on site licensed health care } \\
\text { professionals provide comprehensive medical and wellness care in } \\
\text { an environment that integrates spa services, as well as traditional, } \\
\text { complementary and/or alternative therapies and treatments. The } \\
\text { facility operates within the scope of practice of its staff, which can } \\
\text { include both aesthetic/cosmetic and prevention/wellness } \\
\text { procedures and services }\end{array}$ \\
\hline Club & $\begin{array}{l}\text { A facility whose primary purpose is fitness and that offers a } \\
\text { variety of professional administered spa services on a day-use } \\
\text { basis. A hotel, gym, or fitness club that has a sauna, steam or } \\
\text { whirlpool bath is not a spa unless it explicitly offers spa products } \\
\text { and services as an added benefit }\end{array}$ \\
\hline Mineral springs & $\begin{array}{l}\text { A spa offering an on-site source of natural mineral, thermal or } \\
\text { seawater used in hydrotherapy treatments }\end{array}$ \\
\hline Cruise ship & $\begin{array}{l}\text { A spa aboard a cruise ship providing professionally administered } \\
\text { spa services, fitness and wellness components and spa cuisine } \\
\text { menu choices }\end{array}$ \\
\hline Cosmetic & $\begin{array}{l}\text { A spa that primarily offers aesthetic/cosmetic and } \\
\text { prevention/wellness procedures and services such as facials, peels, } \\
\text { waxing and other non-invasive procedures that are within the } \\
\text { scope of practice of its staff but do not require on-site medical } \\
\text { supervision }\end{array}$ \\
\hline
\end{tabular}

Source: International SPA Association (2010) 
This estimate included $\$ 60.5$ billion in core spa sales and an additional $\$ 194.3$ billion in spa-related industries such as hospitality, tourism, and real estate (Tabacchi, 2010). Health Retreats and Spas are a rapidly growing sector of the tourism industry in general where there has been new interest in "new age" remedies and traditional remedial therapies. Spa selection criteria according to O'Fallon and Rutherford (2011) are determined by a number of factors. An established and known environment for instance, as part of an established resort, club or destination spa, often influences the decision, as does the atmosphere, quality of treatment, and friendliness's of staff. Consumer demand is driving the growth, people are searching for an escape from work related stress, and they are realizing the long-term benefits of taking care of themselves.

O'Fallon and Rutherford (2011) further states that gender demographics also play a role in spa demand, as men are more likely to go for regular weekly visits after business hours or while travelling on business. Women, however, often visit spas during regular business hours (Thacker, 2004; Audi and Wright, 2004; Anderson, 2011). Spa tourism however, is a relatively new concept of tourism in Kenya, hence the introduction of spa resorts and various gyms, health tourism is growing by the day. Most tourists visit the coastal areas to have their bodies covered with special mud which is medicinal for the skin complexion. Available data for health and spa tourism in Kenya is also very limited as a result there is currently no reliable data available on spa tourism consumers and the industry as a whole.

Spa tourism researches have internationally been a field of ongoing concern. Some researchers (Towner \& Wall, 1991; Holloway, 1994) have described the important position of spa tourism and its evolution process in history of tourism development in Europe. The development of spa tourism in different countries or regions also attracts attention of many researchers. These include the development trend, life cycle of the development, and marketing and planning and so on (Kapczynski and Azromek 2008; Loverseed, 1998; Monteson and Singer, 2004; ALEST, 1990; Kaspar, 1985; Norio, 1988). Overall, in the areas which have long been developed, spa's function has been extended gradually from health care to recreations. The term 'spa' can be applied to a town where natural mineral springs are present and to an enterprise or grouping of enterprises offering health treatments based on that source (Lee and King 2009; Smith and Jenner, 2000). Historically, most spas have been developed in the vicinity of thermal and mineral springs. Given the geographic distribution of such resources, taking a spa is commonly associated with coastal locations or in regions of historic interest which have a benign climate. The extent of spa provision is connected to the availability of suitable natural resources including mineral springs, and/or attractive landscapes or climates (Hall, 2003). Towner (1996) proposed that the basic supply components applicable to spas are: accommodation, food and beverage, entertainment, recreational opportunities, health amenities and services, tourist attractions and infrastructure and finally the spa waters themselves. 
The above concepts provide an insight into the various elements which are desirable in a destination which possesses hot springs attributes. A range of natural and man-made tourism attractions and resources has always been a necessary complement to the hot springs themselves. Due to the uniqueness and irreplaceability of these assets, effective destination management will be critical for the achievement of environmental and economic sustainability. Stein et al. (1990) indicated that the key success factors for spa destinations are marketing, location, finance and staff management. Factors generating increased demand for spa tourism in Kenya include:

- Desire for people to become and remain fit and healthy

- An active older generation

- The continued search for the perfect body

- Increasing spend on health and beauty products and treatments to achieve perfect health

\section{Spa Trends}

The following are the on-site Spa industry trends identified by Anderson (2011)

1. Anti-aging treatments and products: Are driving much of spa menu and retail development. Programming and spa menu items include sun damage treatments, chemical peels for skin renewal, and other rejuvenation techniques that build on repeat procedures.

2. Gift card sales: Are driving new users to spas. In the friends and family sector as well as the corporate gift-giving world, day spa certificates are creating demand that is not directly user driven. Third party purchasing brings to spas clients who may not normally have chosen the location or treatment, creating a large but indefinable market demand.

3. Regional specialities: That relate to indigenous and climatic influences continue to create unique spa experiences based on-site-specific supply.

4. Increased stress management: It is important to position services for stress relief, especially to the male business traveler. Spa programming that requires a limited amount of special equipment and minimal changes to a property's infrastructure can do this.

5. Impulse appointments: This trend may result in developing adjunct programs for on-cal staff sources.

6. Shift in perspective: Self-indulgence, pampering, and luxury are being re-evaluated and re-packaged with a new, broader emphasis on self-care, stress relief, and emotional balancing. This is reflected in spa programming, the menu of services, food and beverage outlets, and spa related retail.

7. Changes in demographic use profile: Historically, the greatest segment of spa goers was women between the ages of 35 and 55. More couples and families are expected to visit spa together as an alternative social/ recreational 
activity. This trend has the potential to extend business-related stays, fill business hotels on the weekend, and create demand for destinations.

8. Medical affiliations: For some markets, an affiliation with a medical center or group in the area can be established to provide treatments such as acupuncture, nutritional assessment, laser therapies (hair removal and wrinkle reduction), Botox injections, collagen treatments, chemical peels, laser resurfacing, body contouring, micro-derm abrasion, and vascular procedures.

9. Green environments: A spa can be ecologically sensitive by incorporating environmentally friendly features into the operation. By proactively supporting programs and products that are earth friendly, the spa does something good for the environment, provides a service to the community, and creates a competitive advantage and a unique selling point that may provide significant returns, especially in a highly competitive market.

\section{The Spa Experience \& Challenges}

The primary reasons for visiting spas were to relax and unwind from the pressures of work and day to day life and also to be pampered. On a secondary level, fitness, outdoor sports activities health and physical well being are important reasons. Cosmetic spa which specializes in medical treatment such as skin smoothing laser treatments, facelifts, Botox or treatments for cellulite and body shaping are also gaining popularity in the industry. In terms of having a positive spa experience, a relaxed atmosphere / ambience and a high level of customer service were paramount. Location and surroundings were also found to be important, along with issues such as good food, a variety of treatments and facilities on offer, good quality accommodation where appropriate and value for money. In terms of treatment and product offerings, the following are mostly requested by tourists:

- Massages remain the popular treatment

- Non-traditional products such as "Eastern" treatments and products with fitness components

- Traditional products - therapies like hydrotherapy and mud baths

- Keeping a healthy body and mind (holistic approach) and using natural and organic materials

- Services for couples as dual massages and beach massages are becoming more popular

According to the International Spa Association (2010) Composition of spa types remained similar to previous years. Day spas comprise an overwhelming majority of establishments (79 percent); resort/hotel spas comprise the second largest segment (8.8 percent), with medical spas a close third (8.7 percent).

Other spa types include Club, Mineral Springs and Destination spas. Spa establishments account for 76 million square feet of indoor space, made up of dedicated treatment rooms, as well as a retail element. Two in three spas 
contain massage-only treatment rooms; 71 percent contain skin-care only rooms. Four in ten spas contain hair styling stations, one in two contain makeup stations. Manicure/pedicure stations are found in 85 percent of resort/hotel spas and 65 percent of day spas. Spas received an estimated 143 million client visits in 2009.

The primary treatments provided by spas are body or skin-care services, including facials, scrubs and wraps (94 percent); massage services ( 86 percent), and salon services (68 percent). Wellness programs, including weight management and healthy eating, are offered by 17 percent of spas; and one in ten spas offer fitness or sports services. Four main spa treatment and service categories - massage and bodywork, skin care, hair and nail - account for 78 percent of total spa revenue, though average treatment numbers vary considerably by spa type. Retail accounts for 12 percent of spa revenue, with skin- and hair-care products accounting for the majority of spending in most spas. The spa industry employed over 330,000 people during the spring of 2010. However, spas still serve a predominantly female clientele. Increasingly, teens are going to spas for spa treatments and they, along with young adults, should not be ignored. Within the spa industry, there are still challenges to consider. The growing emphasis on spas and spa treatments is not guaranteed to remain popular. Trends come and go, and without proper planning today's hot item can turn into tomorrow's old news. With this in mind, spa providers need to keep an open mind and prepare for the future.

Currently women are more prevalent in the spa market with baby-boomers who are female, married and over 50 representing the core market for spas. However, reports indicate that there are an increasing number of men seeking spa therapy. In response to this increased interest by men, some spas have begun gearing services specifically towards men. Similar to men, the percentage of young people going to the spa is rising. Along with men, the teens segment is one of the fastest growing areas in the spa industry. The majority of spa goers consider themselves to be in good health; however, they worry about health concerns. Younger spa goers also worry about health concerns and are seeking preventive services for stress-related conditions. Two other, products and technology, play just as important a role as the previously mentioned challenges. These two areas, competitively speaking, must be constantly evaluated, adapted and adjusted. Providing the appropriate combination of services is crucial.

Product trends are many and varied. Spas are moving towards a more comprehensive array of treatments, services and activities combined in a highly conceptualised setting. A product trend growing in popularity is the use of nontraditional products such as 'Eastern' treatments. The Eastern or Asian influence has impacted on products, services and spa design. Body treatments using herbs and other natural ingredients are also growing in popularity. There also appears to be an increased importance of branding in the spa market. Branded spas are known regionally and nationally. The challenge is determining the appropriate set of offerings to carry for one's clientele. Technology usage has advanced in the spa industry because spas now report 
major investments in database management, integrated channel contact systems and marketing products/ services online.

Spa users, especially resort and destination spa users, use the internet to obtain spa and/or pricing information. Making information easily accessible and staying up to date with technological advances are major challenges when attempting to make a spa more appealing than the competition.

\section{Methodology}

The study employs a mixed methodological approach that includes surveys with the establishment and participant observation, existing literature, as well as short-informal interviews. Seven accommodation establishments which were currently offering Spa treatments were surveyed and agreed to short informal interviews. As participant observer, the researcher visited all the establishments at different times noting the differences in terms of ambience, decor, design, products and function of the facilities. Secondary data has been derived from numerous articles in the subject in journals, news outlets, books and the Internet.

\section{Findings and Discussions}

The research findings concerning spa facilities in Kenya has been grouped as follows: (1) Profile of facilities (2) Types of services and treatment (3) Challenges faced in the industry

\section{A. Profile of Facilities}

The facilities were hotel spas established between 1997 and 2008. Three of the Spas had Swahili names such as "Afya Bora" (Good Health); "Tulia" (Relax), "Maisha" (Life). The facilities had between 4 and 7 employees most of whom are female and having a diploma in beauty therapy. Six establishments were a hotel/resort spa and one was a health club spa. The spas were marketed through the word of mouth, brochures, internet, tour operators and family and friends. The average age of visitors to the spa is between 14 and 70 years with a ration of 50:50 for both male and female. Consumers are increasingly seeking the spa experiences as an alternative or complement to other leisure activities. In Kenya, some spa establishments are offering spa therapy schedules for visitors for use when they get back to their countries. Also others have incorporated Spa cuisine and Spa bar and Spa directory and lounge. Only one establishment is the only one in East African Region to belong to the International Spa Association. Health Retreats and spas are sought largely by people who are in high stress positions of employment in the cities. Business travellers in particular appear to be dealing with more stress and jet lag and are booking hotels that offer full-fledged spa services. 
The core market for spas/ health retreats are baby boomers who are very keen, and very willing, to spend on preventing those health conditions that are potentially going to stop them in their tracks - they demand preventative services. Younger professionals are also seeking preventative services for stress related/burn out conditions that are impacting them far too early in life. Research done by the International Spa Association (2011) indicates that the majority of spa clients are female, married, and over age 50. Another age group is of 34 to 52-year-olds who make up a large part of the market, and men account for a quarter of spa users. There is an increasing number of men seeking spa therapy, especially massage. Group bookings have also increased dramatically in recent years. Groups of friends (both female and male), couples, and families (mothers/daughters) are going to spas together.

\section{B. Product Treatments and Services}

Spa treatments are the services that a spa provides. The most popular spa treatments are massages (Table 2) and has a number of health benefits. Other popular spa treatments include facials and different kinds of body treatments baths, scrubs and wraps. Many of the spas also have nail salons, for spa manicures and pedicures; hair salons for both men and women. Also most facilities have Jacuzzi, sauna and steam; Eucalyptus inhaler; hot tubs and floating pools.

Table 2. Spa Treatments in Kenya

\begin{tabular}{|c|l|}
\hline SERVICE & \multicolumn{1}{|c|}{ TYPES } \\
\hline Western and Oriental Massages & $\begin{array}{l}\text { Hot-Stone therapy; deep tissues de-stress; Cellutox; } \\
\text { Musclease; aromatherapy; Swedish massage; foot } \\
\text { and hand massage; Hydrotherapy treatments; } \\
\text { Holistic massages }\end{array}$ \\
\hline Skin Detox Body Wraps & $\begin{array}{l}\text { Mud body wraps; Elimination wrap; Ahava; } \\
\text { Botanic; Detoxifying parafango; Aloe Vera; Dead } \\
\text { Sea Salt Scrub }\end{array}$ \\
\hline Ayurveda Treatments & $\begin{array}{l}\text { Abhyangam with steam bath; Shirodhara; } \\
\text { Navarikizhi; Indian head massage; Pizchil (joint } \\
\text { pains); Elakhizi (backache and muscle pain); } \\
\text { slimming massage treatments }\end{array}$ \\
\hline Japanese Healing Art & Shiatsu and Reiki \\
\hline Refloxology and Ear Candling & Ear waxing and noxious toxins \\
\hline Traditional African Wellness & $\begin{array}{l}\text { Foot reviver; royal scalp massage; Kenya Kahawa } \\
\text { (coffee) scrub in Moroccan Rassoul; African } \\
\text { papaya \& Rose body glow with Cleopatra milk bath }\end{array}$ \\
\hline Rituals & Waxing; Facials; Grooming \\
\hline Body treatments &
\end{tabular}

Source: Okech 2011

\section{Challenges in Promoting Spa Tourism in Kenya}

The spa industry is relatively new in Kenya and the respondents certainly have faced challenges in terms of marketing and promoting spa tourism. These include: 
1. Competition: There is a lot of competition especially with some businesses offering beach massage services at lower rates. These of course reduce the number of clients that would have otherwise patronised the spa establishments in the hotels and resorts.

2. Hygiene: proper hygiene conditions are lacking in some establishments which offer lower services for the same products.

3. Products: these are very expensive to ship especially from Europe as a result, the costs of spa treatments are very high and some tourists do not want to pay the high charges. However, most establishments are coming up with alternative products having the same effects.

4. Lack of conception to what a massage is: guests who are uncooperative and want more than the massage service. The aspect of religion and tradition comes into play where women are allowed to touch only women.

5. Lack of proper training: most people are not trained well in the area of Spa therapy most employees have basic massage knowledge and not in other treatment areas.

There is therefore an urgent need to educate consumers given the results in this study. Many consumers are still not clear on what a spa is and do not see themselves in the spa market. Making the experience relevant to the consumer is important. Many consumers are focused on health, prevention and fitness, but do not realise the connection between spas and wellness. This paradigm shift according to McNeil Ragins (2005) creates a challenge for spa marketers as they attempt to meet their consumers' needs effectively. Spa consumers are looking for a nurturing and healing place where they can enjoy community time, and have shared experiences with friends, relatives and spouses. Less emphasis is being placed on physical appearance and more on inner balance and well-being. Spas are providing more opportunities for improving the mind and body. Another challenge for spa marketers is staying abreast of the changes in the spa consumer profile.

\section{Conclusion}

From this study, it can be seen that the industry is still relatively new and no figures are available to really determine the growth of the industry. However, there is considerable interest given that most of the establishments have spas and some have changed the names of the hotel establishment to include the word spa. This is a marketing tool and strategy as more and more tourists are demanding this experience. Taking all these into consideration the spa industry in Kenya has a huge potential for growth and market. The spa products and treatments are inclusive of the African/Asian/European influences in competition with international standards. It has already been established that day spas continue to dominate the industry in terms of number of establishments; but resort/hotel spas are gaining ground. Europe and Asian influence continues to be very strong in the industry, influencing products, services and spa design. 
There is a strong trend towards "medical type" products and services. Food- and plant-based treatments have also gained widespread popularity. Spas are responding to the increasing interest by males by gearing some services specifically to men and teen market. Many people no longer see the spa as "pampering", but as a requisite to stay healthy and look good. These consumers want simplicity in their spa experiences and are returning to more traditional spa products. Consumers' limited free time means they have less time available to spend at the spa, and the industry is designing its offerings around this trend. The industry's use of technology has advanced in the past two years and Kenya is on par to conform the industry's standards. Spas have moved beyond the use of the Internet as a simple research or e-mail tool, and now report major investments in database management, integrated channel customer contact systems and marketing products/services online.

\section{References}

ALEST (International Association of Scientific Experts in Tourism) (1990). From Traditional Spa Tourism to Modern Forms of Health Tourism, Travel Research, 28(3): 38-39.

Anderson, P.C. (2011) Spas and the Lodging Industry. In O'Fallon, M.J. and Rutherford, D.G. (Eds.) Hotel Management and Operations $-5^{\text {th }}$ Edition. John Wiley and Sons.

Audi, L. and Wright, B. (2004) Compensation Workbook for the Spa Industry. Chicago: Compensation Consulting Consortium.

Foster, A. and Mandelbaum, R. (2005) Hotel Spas: The New Recreational Vehicle for Hotel Profits. www.pkfc.com/common/industry . Accessed 27 ${ }^{\text {th }}$ March, 2012.

Hall, C.M. (2003). Spa and Health Tourism. New York: The Haworth Hospitality Press.

Holloway, C.J. (1994). On Tourism - The 21st century Course in Tourism [M]. Beijing: Encyclopedia of China Publishing House, 1997 (in Chinese).

Kapczynski A. \& Szromek R. A. (2008). Hypotheses Concerning the Development of Polish Spas in the Years 1949-2006. Tourism Management, 29(5): 1035-1037.

Kaspar, C. (1985). A New Lease for Spa and Health Tourism. Annals of Tourism Research, 17(2): 298-299.

Lee, C.F. and King, B. (2009) A Determination of Destination Competitiveness for Taiwan's Hot Springs Tourism Sector Using the Delphi Technique. Journal of Vacation Marketing 15(3): 243-257

Loverseed, H. (1998). Health and Spa Tourism in North America. Travel and Tourism Analyst, Vol 1: 46-66.

Madanoglu, M. and Brezina, S. (2011) Resort Spas: How are they Massaging Hotel Revenues? In O'Fallon, M.J. and Rutherford, D.G. (Eds.) Hotel Management and Operations $-5^{\text {th }}$ Edition. John Wiley and Sons.

McNeil, K.R. and Edna J. Ragins, E.J. (2005) Staying in the Spa Marketing Game: Trends, Challenges, Strategies and Techniques. Journal of Vacation Marketing, 11(1): 31-39.

Monteson, A. P. \& Singer, J. (2004). Marketing a Resort-based Spa. Journal of Vacation Marketing, 10(3): 282-287. 
Smith, C. and Jenner, P. (2000). Health Tourism in Europe. Travel and Tourism Analyst 1: 41-59.

Stanford Research Institute (2008). The global spa economy 2007. Presented in New York City, May.

Stein, T. J., Dev, C. S. and Tabacchi, M. H. (1990) Spas: Redefining the Market. Cornell Hotel and Restaurant Administration Quarterly 30(4): 46-52.

Tabacchi, M.H. (2010) Current Research and Events in the Spa Industry. Cornell Hospitality Quarterly, 51(1): 102-117.

Thacker, G. (2004) Spa Industry Study: A Profile of the Spa Industry in the United States and Canada. Toronto: Association Resource Centre, Inc Research and Strategy Division.

Towner, J. (1996). An Historical Geography of Recreation and Tourism in the Western World 1540-1940. New York: John Wiley and Sons.

Towner, J and Geoffrey, W. (1991). History and Tourism. Annals of Tourism Research, 18(1): 71-84.

XU Jufeng, X. and Wei, G. (n.d) An Empirical Study on Characteristics and Evaluation of the Spa Consumer Market in Beijing. Accessed from www.seio fbluemountain.com on $18^{\text {th }}$ March 2012. 
